\title{
Distribution of mating-type alleles and M13 PCR markers in the black leaf spot fungus Mycosphaerella fijiensis of bananas in Brazil
}

C.B. Queiroz ${ }^{1}$, E.C. Miranda ${ }^{1}$, R.E. Hanada ${ }^{2}$, N.R. Sousa ${ }^{1}$, L. Gasparotto ${ }^{3}$, M.A. Soares $^{4}$ and G.F. Silva ${ }^{1}$

\author{
${ }^{1}$ Laboratório de Biologia Molecular, Embrapa Amazônia Ocidental, \\ Manaus, AM, Brasil \\ ${ }^{2}$ Laboratório de Preservação de Madeira, \\ Instituto Nacional de Pesquisas da Amazônia, Manaus, AM, Brasil \\ ${ }^{3}$ Laboratório de Fitopatologia, Embrapa Amazônia Ocidental, \\ Manaus, AM, Brasil \\ ${ }^{4}$ Instituto de Biociências, Universidade Federal do Mato Grosso, \\ Cuiabá, MT, Brasil
}

Corresponding author: G.F. Silva

E-mail: gilvan.silva@embrapa.br

Genet. Mol. Res. 12 (1): 443-452 (2013)

Received July 11, 2012

Accepted December 20, 2012

Published February 8, 2013

DOI http://dx.doi.org/10.4238/2013.February.8.9

\begin{abstract}
The fungus Mycosphaerella fijiensis is the causative agent of black sigatoka, which is one of the most destructive diseases of banana plants. Infection with this pathogen results in underdeveloped fruit, with no commercial value. We analyzed the distribution of the $M$. fijiensis mating-type system and its genetic variability using M13 phage DNA markers. We found a 1:1 distribution of mating-type alleles, indicating MAT1-1 and MAT1-2 idiomorphs. A polymorphism analysis using three different primers for M13 markers showed that only the M13 minisatellite primers generated polymorphic products. We then utilized this polymorphism to characterize 40 isolates from various Brazilian states. The largest genetic distances were found between isolates from the
\end{abstract}


same location and between isolates from different parts of the country. Therefore, there was no correlation between the genetic similarity and the geographic origin of the isolates. The M13 marker was used to generate genetic fingerprints for five isolates; these fingerprints were compared with the band profiles obtained from inter-simple sequence repeat (UBC861) and inter-retrotransposon amplified polymorphism analyses. We found that the M13 marker was more effective than the other two markers for differentiating these isolates.

Key words: Musa sp; Polymorphism; Mating-type; ISSR; IRAP

\section{INTRODUCTION}

Bananas are one of the most consumed fruits in the world, and Brazil ranks fourth in terms of banana production (FAO, 2010). Biological stress is one of the major limiting factors for the major banana-producing areas. The disease black sigatoka is caused by the fungus $M y$ cosphaerella fijiensis Morelet and is particularly harmful to bananas. This fungus causes the premature death of leaves, thus reducing the photosynthetic ability of the plant and causing the production of irregular fruit with no commercial value (Gasparotto et al., 2006). Black sigatoka was detected in Brazil in 1998 in the municipalities of Benjamin Constant and Tabatinga in the State of Amazonas (Pereira et al., 1998). The disease has since spread throughout the North, South, Southeast, and Central-West regions, with the exception of the States of Espírito Santo, Rio de Janeiro, Goiás, and the Federal District (Gasparotto et al., 2006).

Since the introduction of the pathogen in Brazil, research efforts have focused on monitoring the spread of the disease and evaluating the genetic diversity of $M$. fijiensis with regard to its new geographic conditions and host cultivars. Understanding the variations within the pathogen population is essential for directing disease control strategies, especially for host breeding programs focused on resistance (McDonald and Linde, 2002). In addition, these studies allow for the detection of new variants in the population (Markell and Milus, 2008; Milus et al., 2009).

The successful adaptation of exotic phytopathogens is strictly related to the genetic variability of the founding population and the presence of susceptible host genotypes and favorable environments. In novel environments, recombinant pathogenic populations are able to adapt and mutate more rapidly than clonal populations (Bui et al., 2008; Hsueh and Heitman, 2008). In wheat, sexual recombination is important for generating novel allelic combinations in Mycosphaerella graminicola that are able to overcome the resistance of the host genotypes (Zhan et al., 2007).

The selection of compatible gametes is essential for successful sexual reproduction in microorganisms. The mating behavior of filamentous Ascomycetes is generally determined by one locus and two functional alleles that are often designated as MAT-1 and MAT-2 (Kerenyi et al., 1999). The most intensively studied mating-type system is that of the yeast Saccharomyces cerevisiae (Gordon et al., 2011). This system is characterized by only one locus, MAT, and two different alleles, MAT $a$ and MAT $\alpha$. Each locus contains two genes that encode homeodomain proteins (a1 and alpha2), which in turn regulate sexual reproduction. Two non-allelic genes, MAT1.1 and MAT1.2, have been reported to enhance the genetic recombination rate in $M$. fijiensis (Conde-Ferráez et al., 2007). 
Given the critical role of reproduction in the adaptation and evolution of pathogenic fungi, it is clear that the analysis of the mating-type distribution in M. fijiensis populations may increase our understanding of the relatedness of the Brazilian population of this pathogen.

Globally, the genetic diversity of $M$. fijiensis populations has been studied using restriction fragment length polymorphism (Carlier et al., 1996; Hayden et al., 2003) and simple sequence repeat (SSR) (Müller et al., 1997; Rieux et al., 2011) analyses. Carlier et al. (1996) reported a high degree of divergence in populations originating from Southeast Asia. However, populations from South America, Africa and the Pacific Islands have a low extent of variability compared to those from Southeast Asia (Hayden et al., 2003; Fahleson et al., 2009). Müller et al. (1997) used SSR analysis to demonstrate that the genetic variability of $M$. fijiensis isolates depends on the lesion, plant, cultivar, and location where the phytopathogen was collected. Each technique is unique and demonstrates a different discriminatory power; thus, analyses using various markers may increase our understanding of the genetic diversity in fungal populations.

The genetic variability of pathogenic populations has been analyzed using several different molecular markers (Zein et al., 2010; Nusaibah et al., 2011). The most commonly used marker techniques include inter-simple sequence repeat (ISSR) analysis, which has been widely used to study fungal variability (Neal et al., 2011), and the analysis of inter-retrotransposon amplified polymorphisms (IRAPs), which is a readily accessible method owed to the availability of sequencing databases and the abundance of retrotransposons in the genomes of many organisms (Zein et al., 2010).

Genetic fingerprinting is a robust tool for detecting the presence of pathogens and is useful for molecular screening and diagnosis. Ryskov et al. (1988) first proposed the use of the M13 phage as a universal marker because it can be used to rapidly generate a DNA fingerprint from organisms belonging to distinct taxonomic groups (Degen et al., 1995). This technique has been called M13 fingerprinting (Ulrich et al., 2009), M13 random amplified polymorphic DNA (RAPD) analysis (Rossetti and Giraff, 2005) and M13 minisatellite analysis (Zamponi et al., 2007). In fungi, M13 fingerprinting has been used to analyze genetic instability in Cryptococcus neoformans during the infection stage (Ulrich et al., 2009) and to genetically characterize both the Histoplasma capsulatum (Muniz et al., 2010) and Sporothrix schenckii populations (Reis et al., 2009). M13 fingerprinting has also been used to identify different Trichophyton varieties (Gräser et al., 1998) and to distinguish between Penicillium commune and $P$. palitans (Kure et al., 2002).

Because knowledge of the behavior of $M$. fijiensis under Brazilian conditions is necessary for guiding black sigatoka control strategies, the goal of this study was to analyze the mating-type distribution and genetic variability of $M$. fijiensis isolates using M13 markers.

\section{MATERIAL AND METHODS}

\section{Isolation and culture conditions}

These studies were performed at the Laboratórios de Fitopatologia e Biologia Molecular da Embrapa da Amazônia Ocidental, Amazonas, Brazil. The M. fijiensis isolates were obtained from banana leaves showing disease symptoms and maintained using potato dextrose agar media at $27^{\circ} \mathrm{C}$. Mycelial masses were cultured in potato dextrose medium at $25^{\circ} \mathrm{C}$ and $120 \mathrm{rpm}$ for 2 weeks. 


\section{DNA extraction}

DNA was extracted from $M$. fijiensis mycelia that were ground in liquid nitrogen according to the method described by Specht et al. (1982). The extracted DNA was quantified using a spectrophotometer (NanoDrop) and confirmed by electrophoresis with a $0.8 \%$ agarose gel.

\section{Mating-type analysis}

The MAT1-1-1 and MAT1-2-1 target genes from 131 isolates were analyzed by PCR. The primer sequences were described by Arzanlou et al. (2010): MAT1.1F 5'-CATGAGCACGCTGCAGCAAG-3', MAT1.1R - 5'-GTAGCAGTGGTTGACCAGGTCA T-3', MAT1.2F - 5'-GGCGCTCCGGCAAATCTTC-3', and MAT1.2R - 5'-CTTCTCGGATG GCTTGCGTG-3'. The reactions were performed in a final volume of $15 \mu \mathrm{L}$ using $50 \mathrm{ng}$ DNA, $1 \mathrm{X}$ buffer $(500 \mathrm{mM} \mathrm{KCl}, 100 \mathrm{mM}$ Tris- $\mathrm{HCl}, \mathrm{pH} 8.4$, and $1 \%$ Triton X-100), $2 \mathrm{mM} \mathrm{MgCl}$, $0.15 \mathrm{mM}$ of each dNTP, $0.25 \mu \mathrm{M}$ of each primer and $0.4 \mathrm{U}$ Taq-DNA polymerase (Phoneutria). The temperature cycles used for the amplifications were as follows: an initial 2-min denaturation at $94^{\circ} \mathrm{C}, 40$ cycles of $94^{\circ} \mathrm{C}$ for $1 \mathrm{~min}, 70^{\circ} \mathrm{C}$ for $30 \mathrm{~s}$ and $72^{\circ} \mathrm{C}$ for $1 \mathrm{~min}$, and a final 10 min extension at $72^{\circ} \mathrm{C}$.

\section{M13 analysis}

The M13 minisatellite marker was used to analyze the genetic variability of $40 \mathrm{M}$. fijiensis isolates from the States of Amazonas, Acre, Rondônia, Roraima, Pará, Mato Grosso, and São Paulo (Table 1).

The PCR protocol was optimized using one randomly selected sample. The tested DNA concentrations ranged from 25 to $100 \mathrm{ng}$, the primer concentrations ranged from 0.2 to $0.6 \mu \mathrm{M}$, and the $\mathrm{MgCl}_{2}$ concentrations ranged from 1.5 to $4.0 \mathrm{mM}$. The following primers were used: M13mp18F - GTACTGGTGACGAAACTC, M13mp18R ATCGATAGCAGCACCGTA (Degen et al., 1995), M13 - TTATGTAAAACGGCCAGT, and M13 minisatellite - GAGGGTGGCGGTGGTTCT (Vassart et al., 1987). The reactions were performed in a final volume of $20 \mu \mathrm{L}$ that contained $0.6 \mathrm{mM}$ of each dNTP, $1 \mathrm{X}$ buffer (500 mM KCl, $100 \mathrm{mM}$ Tris-HCl, $\mathrm{pH} 8.4$, and $1 \%$ Triton X-100) and 1 U Taq DNA polymerase (Phoneutria). The amplification cycle was as follows: an initial 4-min denaturation at $94^{\circ} \mathrm{C}, 35$ cycles of $94^{\circ} \mathrm{C}$ for $1 \mathrm{~min}, 49^{\circ} \mathrm{C}$ for $1 \mathrm{~min}$ and $72^{\circ} \mathrm{C}$ for $2 \mathrm{~min}$, and a final extension at $72^{\circ} \mathrm{C}$ for $10 \mathrm{~min}$. The ideal annealing temperature for the primers was determined by varying the temperature from $46^{\circ}$ to $61^{\circ} \mathrm{C}$. The $\mathrm{PCR}$ optimization tests indicated that $0.6 \mathrm{mM}$ primer, an annealing temperature of $46^{\circ} \mathrm{C}$ and $25 \mathrm{ng}$ DNA maximized the amplicon quality. The $\mathrm{MgCl}_{2}$ concentrations varied depending on the primer used, with 2.5, 3.0, and $2.0 \mathrm{mM}$ required for M13mp, M13 minisatellite and M13, respectively.

\section{ISSR and IRAP analysis}

Five isolates (Mf141, Mf195, Mf205, Mf217, and Mf218) were selected for comparisons of their M13, ISSR and IRAP fingerprints. 


\begin{tabular}{|c|c|c|c|}
\hline \multirow[t]{2}{*}{ Isolate } & \multirow[t]{2}{*}{ Host } & \multicolumn{2}{|c|}{ Geographic information } \\
\hline & & State/municipality & GPS coordinates \\
\hline & & Amazonas & \\
\hline Mf02 & Thap Maeo & Presidente Figueiredo & $\mathrm{S} 02^{\circ} 03346 \mathrm{~W} 59^{\circ} 40047$ \\
\hline Mf 05 & Thap Maeo & Presidente Figueiredo & $\mathrm{S} 02^{\circ} 03329 \mathrm{~W} 59^{\circ} 34650$ \\
\hline Mf 07 & Thap Maeo & Manacapuru & $\mathrm{S} 03^{\circ} 16252 \mathrm{~W} 60^{\circ} 30539$ \\
\hline Mf 37 & Maçã & Rio Preto da Eva & $\mathrm{S} 02^{\circ} 42956 \mathrm{~W} 59^{\circ} 41802$ \\
\hline $\operatorname{Mf} 41$ & Maçã & Rio Preto da Eva & $\mathrm{S} 02^{\circ} 51594 \mathrm{~W} 59^{\circ} 24414$ \\
\hline Mf 44 & Prata comum & Manaus & $\mathrm{S} 02^{\circ} 59042 \mathrm{~W} 60^{\circ} 05587$ \\
\hline Mf 62 & Maçã & Manacapuru & $\mathrm{S} 03^{\circ} 16511 \mathrm{~W} 60^{\circ} 38280$ \\
\hline Mf 63 & Prata comum & Manacapuru & $\mathrm{S} 03^{\circ} 16509 \mathrm{~W} 60^{\circ} 38279$ \\
\hline Mf 68 & IAC 2001 & Manacapuru & 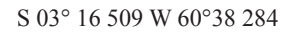 \\
\hline Mf 99 & D'Angola & Iranduba & $\mathrm{S} 03^{\circ} 11633 \mathrm{~W} 60^{\circ} 08392$ \\
\hline Mf 100 & Prata comum & Iranduba & $\mathrm{S} 03^{\circ} 10035 \mathrm{~W} 60^{\circ} 06341$ \\
\hline Mf 102 & Maçã & Iranduba & $\mathrm{S} 03^{\circ} 08372 \mathrm{~W} 60^{\circ} 14286$ \\
\hline Mf 127 & Caru Roxa & Presidente Figueiredo & - \\
\hline Mf 134 & Prata comum & Atalaia do Norte & $\mathrm{S} 04^{\circ} 22598 \mathrm{~W} 70^{\circ} 10356$ \\
\hline Mf 136 & SH 3640 & Tabatinga & $\mathrm{S} 04^{\circ} 13210 \mathrm{~W} 69^{\circ} 55067$ \\
\hline Mf 138 & D'Angola & Tabatinga & $\mathrm{S} 04^{\circ} 08236 \mathrm{~W} 69^{\circ} 56767$ \\
\hline Mf 141 & Maçã & Autazes & $\mathrm{S} 03^{\circ} 34790 \mathrm{~W} 59^{\circ} 41560$ \\
\hline Mf 150 & Prata comum & Itacoatiara & $\mathrm{S} 03^{\circ} 03520 \mathrm{~W} 58^{\circ} 50140$ \\
\hline Mf 158 & D’Angola & Autazes & $\mathrm{S} 03^{\circ} 36153 \mathrm{~W} 59^{\circ} 30813$ \\
\hline Mf 160 & Nanica & Careiro Castanho & - \\
\hline Mf 188 & Maçã & Itacoatiara & - \\
\hline Mf 195 & D'Angola & Itacoatiara & $\mathrm{S} 03^{\circ} 07088 \mathrm{~W} 59^{\circ} 05945$ \\
\hline Mf 224 & Nanica & Iranduba & $\mathrm{S} 03^{\circ} 13933 \mathrm{~W} 60^{\circ} 06836$ \\
\hline \multirow[t]{2}{*}{ Mf 225} & Nanica & Iranduba & $\mathrm{S} 03^{\circ} 16456 \mathrm{~W} 60^{\circ} 11647$ \\
\hline & & Roraima & \\
\hline Mf 118 & Maçã & Caroebe & - \\
\hline Mf 119 & Pacovan & Caroebe & $\mathrm{S} 00^{\circ} 47820 \mathrm{~W} 59^{\circ} 25749$ \\
\hline Mf 120 & Maçã & Caroebe & $\mathrm{S} 00^{\circ} 48268 \mathrm{~W} 59^{\circ} 25838$ \\
\hline Mf 121 & Pacovan & Caroebe & - \\
\hline Mf 130 & Pacovan & Caroebe & $\mathrm{S} 00^{\circ} 53040 \mathrm{~W} 59^{\circ} 41864$ \\
\hline \multirow[t]{2}{*}{ Mf 131} & Pacovan & Caroebe & $\mathrm{S} 00^{\circ} 47875 \mathrm{~W} 59^{\circ} 25837$ \\
\hline & & Pará & \\
\hline \multirow[t]{2}{*}{ Mf 139} & Caipira & Marituba & - \\
\hline & & Rondônia & \\
\hline \multirow[t]{2}{*}{ Mf 175} & Caru roxa & Porto Velho & $\mathrm{S} 08^{\circ} 40367 \mathrm{~W} 63^{\circ} 49810$ \\
\hline & & Acre & \\
\hline \multirow[t]{2}{*}{ Mf 196} & ST 1231 & Rio Branco & $\mathrm{S} 10^{\circ} 01591 \mathrm{~W} 67^{\circ} 42394$ \\
\hline & & Mato Grosso & \\
\hline \multirow[t]{2}{*}{ Mf 82} & IAC 2001 & Cáceres & $\mathrm{S} 16^{\circ} 09147 \mathrm{~W} 57^{\circ} 37914$ \\
\hline & & São Paulo & \\
\hline Mf 201 & Nanicão & Pedro de Toledo & $\mathrm{S} 24^{\circ} 16819 \mathrm{~W} 47^{\circ} 13139$ \\
\hline Mf 205 & Prata anã & Miracatu & $\mathrm{S} 24^{\circ} 18239 \mathrm{~W} 47^{\circ} 29349$ \\
\hline Mf 217 & Prata anã & Jacupiranga & $\mathrm{S} 24^{\circ} 43328 \mathrm{~W} 48 \mathrm{O} 04210$ \\
\hline Mf 218 & . & Jacupiranga & $\mathrm{S} 24^{\circ} 42185 \mathrm{~W} 48 \mathrm{O} 00607$ \\
\hline Mf 219 & Maçã & Pariquera-Açu & $\mathrm{S} 24^{\circ} 37070 \mathrm{~W} 47 \mathrm{O} 53106$ \\
\hline Mf 220 & Nanicão & Pariquera-Açu & $\mathrm{S} 24^{\circ} 36498 \mathrm{~W} 47 \mathrm{O} 53568$ \\
\hline
\end{tabular}

The ISSR amplification reactions were performed in a final volume of $20 \mu \mathrm{L}$ containing 50 ng DNA, $1 \mathrm{X}$ buffer $(500 \mathrm{mM} \mathrm{KCl}, 100 \mathrm{mM}$ Tris-HCl, $\mathrm{pH} 8.4$, and 1\% Triton X-100), $1.5 \mathrm{mM} \mathrm{MgCl}, 0.15 \mathrm{mM}$ of each dNTP, $0.75 \mu \mathrm{M} \mathrm{UBC} 861$ - (ACC) ${ }_{6}$ primer and $1 \mathrm{U}$ Taq DNA polymerase (Phoneutria). The following amplification conditions were used: $94^{\circ} \mathrm{C}$ for $3 \mathrm{~min}$ for the initial denaturation followed by 40 cycles of $94^{\circ} \mathrm{C}$ for $30 \mathrm{~s}, 60.6^{\circ} \mathrm{C}$ for $1 \mathrm{~min}$ and $72^{\circ} \mathrm{C}$ for $2 \mathrm{~min}$, and a final $7-\mathrm{min}$ extension at $72^{\circ} \mathrm{C}$. 
The IRAP amplification reactions were performed in a final volume of $20 \mu \mathrm{L}$ containing 50 ng DNA, $1 \mathrm{X}$ buffer $(500 \mathrm{mM} \mathrm{KCl}, 100 \mathrm{mM}$ Tris- $\mathrm{HCl}, \mathrm{pH} 8.4$, and $1 \%$ Triton X-100), $2.0 \mathrm{mM} \mathrm{MgCl}, 0.05 \mathrm{mM}$ of each dNTP, $0.5 \mu \mathrm{M}$ of each primer and 1 $\mathrm{U}$ Taq DNA polymerase (Phoneutria). The primers were designed using the M. fijiensis retrotransposon: LTRMf-F - 5'-GCGCTTAGCGTTAGGCTAACT-3' and LTRMf-R 5'-CGTGTAGCCTCTTTGGCCCTA-3'. The amplification conditions were as follows: $95^{\circ} \mathrm{C}$ for $15 \mathrm{~s}$ for the initial denaturation, $95^{\circ} \mathrm{C}$ for $15 \mathrm{~s}, 60^{\circ} \mathrm{C}$ for $1 \mathrm{~min}, 68^{\circ} \mathrm{C}$ for $2 \mathrm{~min}$, and a final 5 -min extension at $68^{\circ} \mathrm{C}$.

\section{Data analysis}

The band profiles generated from the reactions were visualized using a 1.5\% agarose gel. A binary matrix was then generated based on the absence (0) or presence (1) of bands and analyzed using the NTSYS 2.1 program.

The unweighted pair group method with arithmetic mean (UPGMA) and the sequential, agglomerative, hierarchical, and non-overlapping (SAHN) methods were used to construct a dendrogram based on Dice similarity coefficients.

\section{RESULTS}

\section{M. fijiensis mating-type}

The 129 isolates analyzed contained or lacked a fragment with an expected size of approximately $700 \mathrm{bp}$ for both MAT1-1-1 and MAT1-2-1. A complete population consisting of isolates from six states exhibited an equal 1:1 distribution of mating-types, indicating that sexual recombination occurs in the Brazilian M. fijiensis population. A ratio close to 1 was also observed for the groups of isolates from the States of Amazonas, Roraima and São Paulo (Table 2).

Table 2. Chi-squared $\left(\chi^{2}\right)$ test results and the ratio, total number of isolates $(\mathrm{N})$ and number of isolates of each
mating-type for each state.
\begin{tabular}{lccccc} 
State & $\mathrm{N}$ & MATl.1 & MATl.2 & Ratio & $\chi^{2}$ \\
\hline Acre & 5 & 0 & 5 & 0 & 5 \\
Amazonas & 78 & 40 & 38 & 1.05 & 0.05 \\
Mato Grosso & 11 & 1 & 7 & 0.57 & 0.8 \\
Rondônia & 3 & 8 & 7 & 1.5 & 0.33 \\
Roraima & 15 & 10 & 7 & 1.4 & 0.53 \\
São Paulo & 17 & & & & \\
\hline
\end{tabular}

\section{M13 marker analysis}

Of the three primer pairs that were evaluated, only the M13 minisatellite pair exhibited polymorphisms, which allowed it to be used for the genetic discrimination of the isolates analyzed.

As shown in the dendrogram, genetic similarity ranged from 0.57 to 1.00 with the 
majority of the isolates sharing the maximum extent of similarity independent of geographic origin (Figure 1). The isolates were divided into two major groups that exhibited a similarity of approximately 0.70 and were interconnected by a single isolate from the State of Roraima. The first group could be divided into three subgroups: the first subgroup contained $85 \%$ of the isolates from various geographic areas, while the two other subgroups primarily contained isolates from the State of Amazonas. The second group comprised two Amazonian isolates and three isolates from São Paulo.

The high levels of genetic relationship between the isolates analyzed may partially be due to the small sample size and the historically recent expansion of the pathogen in the country. However, we should emphasize that there were distinct genetic differences between the major groups identified in the dendrogram, especially for the three isolates from São Paulo (Mf205, Mf217 and Mf218) and the three isolates that originated near or at the location where the pathogen first entered the country, i.e., the municipality of Tabatinga in the State of Amazonas (Mf134, Mf136 and Mf138). Another factor that should be considered is the potential detection of genetic diversity resulting from sexual reproduction and the wide variety of host genotypes that are cultivated in Brazil.

The fingerprinting results obtained using the M13 marker for five isolates were compared to the band profiles obtained using ISSR (UBC861) or IRAP. The M13 fingerprinting method showed the greatest discriminatory power despite the greater number of bands generated by the ISSR and IRAP markers (Figure 2).

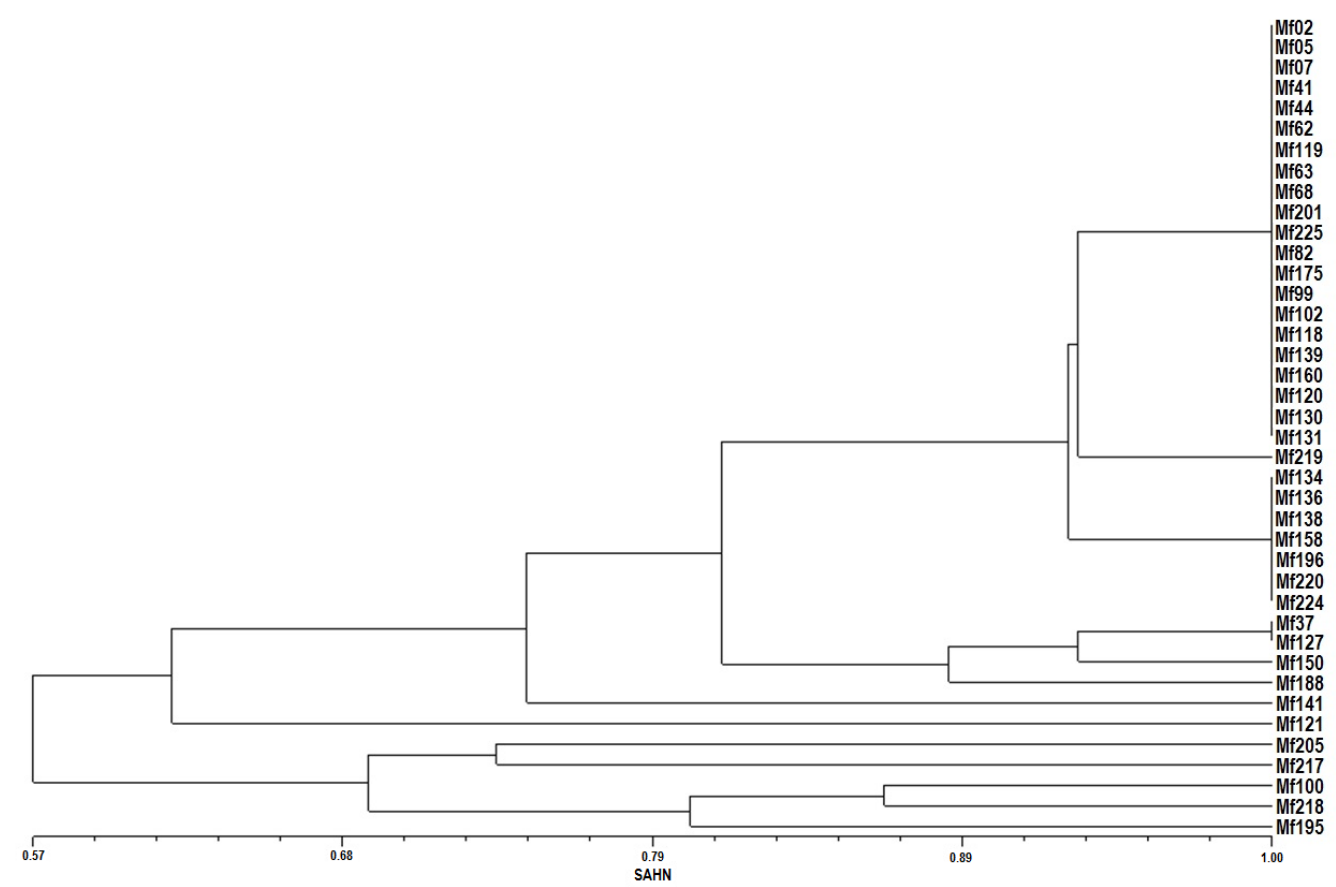

Figure 1. Dendrogram generated using the unweighted pair group method with arithmetic mean based on Dice similarity coefficient. SAHN = sequential, agglomerative, hierarchical, and non-overlapping methods. 


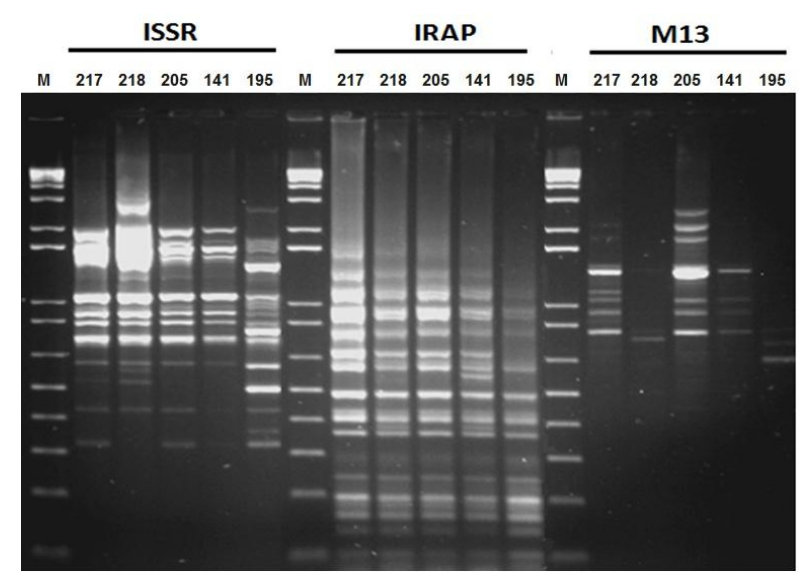

Figure 2. Band profiles derived from inter-simple sequence repeat (ISSR) (UBC861 primer), inter-retrotransposon amplified polymorphism (IRAP) and M13 fingerprinting analyses of five Mycosphaerella fijiensis isolates are shown on a $1.5 \%$ agarose gel. Lane $M=$ DNA molecular marker.

\section{DISCUSSION}

\section{Mating-type}

One would expect sexual reproduction to be an adaptation strategy employed by heterothallic fungal species because the resulting ascospores are highly relevant to pathogenic infections and the pathogen life cycle. The equal distribution of the mating-type alleles observed in this study suggests that sexual reproduction occurs randomly in the Brazilian $M$. fijiensis population.

The distribution of the mating-type alleles does not specifically imply the existence of a sexual stage, although the presence of two idiomorphs at equal frequencies is indicative of sexual recombination in a given population (Linde et al., 2003). Sexual reproduction promotes gene flow between individuals, and rearrangements resulting from crossovers generate new allelic combinations, thereby increasing the amount of genetic variability within the pathogen. In Mexican $M$. fijiensis populations, the equal distribution of mating-type alleles confirms the Mendelian inheritance of these genes (Conde-Ferráez et al., 2010).

In certain fungi, the mechanisms associated with sexual compatibility and development suggest that the mating-type genes are linked to pathogen virulence (Hsueh and Heitman, 2008; Lee et al., 2010). The populations that maintain sexual reproduction are able to generate genetic combinations capable of overcoming the host plant's resistance (Lee et al., 2010). In wheat, significant differences in pathogenicity have been found between the MAT1-1 and MAT1-2 groups of M. graminicola (Zhan et al., 2007).

\section{M13 markers}

A comparison between the results using M13, ISSR and IRAP markers showed that the M13 marker could potentially be applied for M. fijiensis fingerprinting. The M13 minisatellite marker has also been successfully used in Cryptococcus gattii (Ulrich et al., 
2009), C. neoformans (Liaw et al., 2010) and Lactobacillus spp (Mercanti et al., 2011).

The genetic variability of the Brazilian isolates was low and did not show a geographic pattern, which partially corroborates the results from analyses involving populations representative of the pathogen's worldwide distribution. High levels of variation have been observed in the populations from Southeast Asia, which is thought to be the origin of M. fijiensis (Carlier et al., 1994). In the continental regions where the pathogen populations are thought to be derived from founding events (South America, Africa and the Pacific Islands), diversity has been shown to be lower (Hayden et al., 2003; Rivas et al., 2004).

\section{ACKNOWLEDGMENTS}

Research supported by the Brazilian Agencies CNPq (Conselho Nacional de Desenvolvimento Científico e Tecnológico) and FAPEAM (Fundação de Amparo à Pesquisa do Estado do Amazonas).

\section{REFERENCES}

Arzanlou M, Crous PW and Zwiers LH (2010). Evolutionary dynamics of mating-type loci of Mycosphaerella spp. occurring on banana. Eukaryot. Cell 9: 164-172.

Bui T, Lin X, Malik R, Heitman J, et al. (2008). Isolates of Cryptococcus neoformans from infected animals reveal genetic exchange in unisexual, alpha mating type populations. Eukaryot. Cell 7: 1771-1780.

Carlier J, Mourichon X, Gonzalez-de-Leon D, Zapater MF, et al. (1994). DNA restriction fragment length polymorphisms in Mycosphaerella species that cause banana leaf spot diseases. Phytopathology 84: 751-756.

Carlier J, Lebrun MH, Zapater MF, Dubois C, et al. (1996). Genetic structure of the global population of banana black leaf streak fungus, Mycosphaerella fijiensis. Mol. Ecol. 5: 499-510.

Conde-Ferráez L, Waalwijk C, Canto-Canche BB, Kema GH, et al. (2007). Isolation and characterization of the mating type locus of Mycosphaerella fijiensis, the causal agent of black leaf streak disease of banana. Mol. Plant Pathol. 8: 111-120.

Conde-Ferráez L, Grijalva-Arango R, Canto-Canché BB, Manzo-Sánchez G, et al. (2010). The development of mating type-specific primers for Mycosphaerella fijiensis, the causal agent of black Sigatoka of banana, and analysis of the frequency of idiomorph types in Mexican populations. Australas. Plant Pathol. 39: 217-225.

Degen B, Ziegenhagen B, Gillet E and Scholz F (1995). Computer-aided search for codominant markers in complex haploid DNA banding patterns: A case study in Abies alba MILL. Silvae Genet. 44: 274-282.

Fahleson J, Nakyanzi M, Okori P, Seal S, et al. (2009). Genetic analysis of Mycosphaerella fijiensis in the Ugandan Lake Victoria region. Plant Pathol. 58: 888-897.

FAO (2010). Food and Agricultural Organization. FAOSTAT. Available at [http://faostat.fao.org/site/567/default.aspx]. Accessed July 3, 2012.

Gasparotto L, Pereira JCR, Hanada RE and Montarroyos AVV (2006). Sigatoka-Negra da Bananeira. [Black Sigatoka in Banana Trees]. Embrapa, Brasília.

Gordon JL, Armisen D, Proux-Wera E, OhEigeartaigh SS, et al. (2011). Evolutionary erosion of yeast sex chromosomes by mating-type switching accidents. Proc. Natl. Acad. Sci. U. S. A. 108: 20024-20029.

Gräser Y, El FM, Presber W, Sterry W, et al. (1998). Identification of common dermatophytes (Trichophyton, Microsporum, Epidermophyton) using polymerase chain reactions. Br. J. Dermatol. 138: 576-582.

Hayden HL, Carlier J and Aitken EAB (2003). Genetic structure of Mycosphaerella fijiensis populations from Australia, Papua New Guinea and the Pacific Islands. Plant Pathol. 52: -703.

Hsueh YP and Heitman J (2008). Orchestration of sexual reproduction and virulence by the fungal mating-type locus. Curr. Opin. Microbiol. 11: 517-524.

Kerenyi Z, Zeller K, Hornok L and Leslie JF (1999). Molecular standardization of mating type terminology in the Gibberella fujikuroi species complex. Appl. Environ. Microbiol. 65: 4071-4076.

Kure CF, Abeln ECA, Holst-Jensen A and Skaar I (2002). Differentiation of Penicillium commune and Penicillium palitans isolates from cheese and indoor environments of cheese factories using M13 fingerprinting. Food Microbiol. 19: 151-157.

Lee SC, Ni M, Li W, Shertz C, et al. (2010). The evolution of sex: a perspective from the fungal kingdom. Microbiol. Mol. Biol. Rev. 74: 298-340. 
Liaw SJ, Wu HC and Hsueh PR (2010). Microbiological characteristics of clinical isolates of Cryptococcus neoformans in Taiwan: serotypes, mating types, molecular types, virulence factors, and antifungal susceptibility. Clin. Microbiol. Infect. 16: 696-703.

Linde CC, Zala M, Ceccarelli S and McDonald BA (2003). Further evidence for sexual reproduction in Rhynchosporium secalis based on distribution and frequency of mating-type alleles. Fungal Genet. Biol. 40: 115-125.

Markell SG and Milus EA (2008). Emergence of a novel population of Puccinia striiformis $f$. sp. tritici in Eastern United States. Phytopathology 98: 632-639.

McDonald BA and Linde C (2002). Pathogen population genetics, evolutionary potential, and durable resistance. Annu. Rev. Phytopathol. 40: 349-379.

Mercanti DJ, Carminati D, Reinheimer JA and Quiberoni A (2011). Widely distributed lysogeny in probiotic lactobacilli represents a potentially high risk for the fermentative dairy industry. Int. J. Food Microbiol. 144: 503-510.

Milus EA, Kristensen K and Hovmoller MS (2009). Evidence for increased aggressiveness in a recent widespread strain of Puccinia striiformis $f$. sp. tritici causing stripe rust of wheat. Phytopathology 99: 89-94.

Muniz MM, Morais E Silva Tavares, Meyer W, Nosanchuk JD, et al. (2010). Comparison of different DNA-based methods for molecular typing of Histoplasma capsulatum. Appl. Environ. Microbiol. 76: 4438-4447.

Müller R, Pasberg-Gauhl C, Gauhl F, Ramser J, et al. (1997). Oligonucleotide fingerprinting detects genetic variability at different levels in Nigerian Mycosphaerella fijiensis. J. Phytopathol. 145: 25-30.

Neal CO, Richardson AO, Hurst SF, Tortorano AM, et al. (2011). Global population structure of Aspergillus terreus inferred by ISSR typing reveals geographical subclustering. BMC Microbiol. 11: 203.

Nusaibah SA, Latiffah Z and Hassaan AR (2011). ITS-PCR-RFLP analysis of Ganoderma sp. infecting industrial crops. Pertanika J. Trop. Agric. Sci. 34: 83-91.

Pereira JCR, Gasparotto L, Coelho AFS and Urben AF (1998). Ocorrência da Sigatoka-negra no Brasil. Fitopatol. Bras. $23: 295$.

Reis RS, Almeida-Paes R, Muniz MM, Tavares PM, et al. (2009). Molecular characterisation of Sporothrix schenckii isolates from humans and cats involved in the sporotrichosis epidemic in Rio de Janeiro, Brazil. Mem. Inst. Oswaldo Cruz 104: 769-774.

Rieux A, Halkett F, de Lapeyre de BL, Zapater MF, et al. (2011). Inferences on pathogenic fungus population structures from microsatellite data: new insights from spatial genetics approaches. Mol. Ecol. 20: 1661-1674.

Rivas GG, Zapater MF, Abadie C and Carlier J (2004). Founder effects and stochastic dispersal at the continental scale of the fungal pathogen of bananas Mycosphaerella fijiensis. Mol Ecol 13: 471-482.

Rossetti L and Giraffa G (2005). Rapid identification of dairy lactic acid bacteria by M13-generated, RAPD-PCR fingerprint databases. J. Microbiol. Methods 63: 135-144.

Ryskov AP, Jincharadze AG, Prosnyak MI, Ivanov PL, et al. (1988). M13 phage DNA as a universal marker for DNA fingerprinting of animals, plants and microorganisms. FEBS Lett. 233: 388-392.

Specht CA, DiRusso CC, Novotny CP and Ullrich RC (1982). A method for extracting high-molecular-weight deoxyribonucleic acid from fungi. Anal. Biochem. 119: 158-163.

Ulrich K, Ngamskulrungroj P and Meyer W (2009). M13 PCR fingerprinting detects genetic instability of Cryptococcus gattii after passage through a rat model of infection. Aust. Mycol. 28: 20-23.

Vassart G, Georges M, Monsieur R, Brocas H, et al. (1987). A sequence in M13 phage detects hypervariable minisatellites in human and animal DNA. Science 235: 683-684.

Zamponi L, Paffetti D, Tegli S, Lakomy P, et al. (2007). Genetic variation in Heterobasidion abietinum populations detected with the M13 minisatellite marker. Forest Pathol. 37: 321-328.

Zein I, Jawhar M and Arabi MI (2010). Efficiency of IRAP and ITS-RFLP marker systems in accessing genetic variation of Pyrenophora graminea. Genet. Mol. Biol. 33: 328-332.

Zhan J, Mundt CC and McDonald BA (2007). Sexual reproduction facilitates the adaptation of parasites to antagonistic host environments: Evidence from empirical study in the wheat-Mycosphaerella graminicola system. Int. J. Parasitol. 37: 861-870. 